\title{
Genetic Diversity and Relationships of Two Pathovars of Pseudomonas syringae
}

\author{
By TIMOTHY P. DENNY, ${ }^{*}$ MARION N. GILMOUR ${ }^{2}$ AND \\ ROBERT K. SELANDER ${ }^{2} \dagger$ \\ ${ }^{1}$ Department of Plant Pathology, University of Georgia, Athens, GA 30602, USA \\ ${ }^{2}$ Department of Biology, University of Rochester, Rochester, NY 14627, USA
}

(Received 4 November 1987; revised 25 February 1988)

\begin{abstract}
To determine genetic relationships within and between two pathovars of Pseudomonas syringae, strains typical of $P$. syringae pv. tomato ( $P$. s. tomato) and selected strains of $P$. syringae pv. syringae ( $P$. s. syringae) were characterized by three methods. DNA-DNA hybridization experiments showed that strains of $P$. s. tomato and $P$. s. syringae were, respectively, $86-100 \%$ and $37-47 \%$ homologous to DNA from a $P$. s. tomato reference strain when tested under stringent conditions. An analysis of electrophoretic variation in enzymes encoded by 26 loci placed 17 P. s. tomato strains studied in a group of four electrophoretic types, and these strains had a mean genetic diversity per locus of $0 \cdot 076$. Six $P$. s. syringae strains formed a second group of six electrophoretic types, which had a higher mean genetic diversity per locus of 0.479 . The mean genetic distance separating $P$. s. tomato from $P$. s. syringae $(D=0.94)$ was unexpectedly large for strains of a single species. An analysis of restriction fragment length polymorphisms (RFLPs) with three cloned hybridization probes demonstrated that each of the $P$. s. tomato and $P$. s. syringae strains was unique. A method was developed to quantify the RFLP difference between pairs of strains, and cluster analysis revealed relationships among $P$. $s$. tomato, but not among $P$. s. syringae, that were similar to those based on enzyme polymorphisms. Implications of these findings for bacterial systematics and epidemiology are discussed.
\end{abstract}

\section{INTRODUCTION}

Phenotypic characters do not provide an adequate basis for classifying strains of the fluorescent phytopathogenic pseudomonads (Schroth et al., 1981; Palleroni, 1984). Consequently, all oxidase-negative and arginine-dihydrolase-negative fluorescent bacteria currently are classified as Pseudomonas syringae van Hall (Palleroni, 1984), and infraspecific pathovars have been designated to meet the needs of plant pathologists concerned with differential pathogenicity of strains (Young et al., 1978). Some pathovars of $P$. syringae can be distinguished by phenotypic characters (Schroth et al., 1981; Hildebrand et al., 1982; Denny, 1988), but in the absence of genetic analyses, the evolutionary relationships and taxonomic status of the pathovars have remained problematical.

The only reported genetic studies concerning the taxonomy of $P$. syringae are those of Palleroni et al. (1972) and Pecknold \& Grogan (1973), who used DNA-DNA hybridization to subdivide $P$. syringae into three groups. However, only a small number of strains was studied and genetic diversity within the pathovars was not examined.

The objectives of the research reported here were to assess genetic diversity and evolutionary relationships among strains typical of $P$. syringae pv. tomato (Okabe) Young, Dye \& Wilke ( $P$. $s$. tomato) (Denny, 1988) and a selected sample of $P$. syringae pv. syringae van Hall ( $P$. s. syringae).

† Present address: Department of Biology, Pennsylvania State University, University Park, PA 16802, USA.

Abbreviations: RFLP, restriction fragment length polymorphism; ET, electrophoretic type.

0001-4514 (C) 1988 SGM 
The first of three methods of analysis used was DNA-DNA hybridization, which measures the relatedness of entire genomes and is relatively unaffected by point mutations or insertions and deletions of short DNA sequences (Schleifer \& Stackebrandt, 1983; Johnson, 1984). This insensitivity to small changes makes DNA-DNA hybridization a poor choice for studying closely related strains. The second method used was multilocus enzyme electrophoresis, which relates polymorphic variation in the electrophoretic mobility of enzymes to allelic variation at the corresponding structural genes. Multilocus enzyme electrophoresis is more sensitive to small differences between strains than is DNA-DNA hybridization and has a number of other advantages that make it useful for studying variation within species (Selender et al., 1986). The third method examined the restriction fragment length polymorphisms (RFLPs) revealed by digesting genomic DNA with restriction endonucleases. RFLP analysis is very sensitive to small changes in DNA organization (Nei \& Li, 1979), and has the advantages that it may examine a larger part of the genome than does multilocus enzyme analysis and samples DNA segments without regard to protein coding capacity or expression.

All three methods indicated that the strains of $P$. s. tomato studied are more closely related to each other than to those of $P$. s. syringae, and that the two pathovars are genetically very distinct. These findings have implications for the systematics of these pathovars and provide insight regarding the genetic structure of $P$. s. tomato that will be useful in epidemiological research.

\section{METHODS}

Bacterial strains. The strains of $P$. s. tomato and $P$. s. syringae analysed and media used in culturing are described in the preceding paper (Denny, 1988). Agrobacterium tumefaciens strain A6 was received from A. Binns, Department of Biology, University of Pennsylvania, USA. Escherichia coli strain HB101 was as described in Maniatis et al. (1982).

DNA isolation. Total DNA was prepared from $P$. s. tomato and $P$. s. syringae strains by the method of Silhavy $e t$ al. (1984) with several modifications. Cells were grown overnight at $30^{\circ} \mathrm{C}$ in $10 \mathrm{ml}$ Luria broth (LB: tryptone, $10 \mathrm{~g}$; yeast extract, $5 \mathrm{~g} ; \mathrm{NaCl}, 5 \mathrm{~g}$; water, 1 l). The $\mathrm{OD}_{600}$ of the culture was adjusted to 0.5 with sterile deionized water, and $40 \mathrm{ml}$ of the resulting suspension was centrifuged at $2200 \mathrm{~g}$ for $20 \mathrm{~min}$. The cell pellet was drained and suspended in $2.5 \mathrm{ml}$ of $100 \mathrm{~mm}$-Tris/ $\mathrm{HCl}(\mathrm{pH} 8.0), 100 \mathrm{mM}$-EDTA. Freshly prepared lysozyme solution $(50 \mu \mathrm{l}$ of a $5 \mathrm{mg} \mathrm{ml}^{-1}$ solution in $250 \mathrm{~mm}$-Tris/HCl, $\mathrm{pH} \mathrm{8.0)}$ was added, followed by $2.5 \mathrm{ml}$ sterile deionized water to osmotically shock the cells and enhance enzyme infiltration. The reaction tube was placed on ice for $10 \mathrm{~min}$, then $1.0 \mathrm{ml} \mathrm{STEP}$ buffer $\left(0.5 \%\right.$, w/v, SDS; $50 \mathrm{mM}$-Tris/HCl, pH 7.5;0.4 M-EDTA; $1 \mathrm{mg}$ fresh proteinase $\mathrm{K} \mathrm{ml}^{-1}$ was added with gentle mixing and the tube was incubated at $50{ }^{\circ} \mathrm{C}$ for $30 \mathrm{~min}$. The lysate was extracted once with buffered phenol/chloroform $(1: 1, \mathrm{v} / \mathrm{v})$ and once with chloroform, and the DNA was then precipitated with ethanol and spooled out. The DNA was dissolved in $5.0 \mathrm{ml} 50 \mathrm{~mm}-\mathrm{Tris} / \mathrm{HCl}(\mathrm{pH} 7.5), 1 \mathrm{~mm}$-EDTA, $0.2 \mathrm{mg}$ RNAase $\mathrm{A} \mathrm{ml}^{-1}$ by gentle overnight mixing at $4{ }^{\circ} \mathrm{C}$. The DNA was again extracted, precipitated, and spooled out as above, dissolved in $2.0 \mathrm{ml} \mathrm{TE}$ buffer $(10 \mathrm{mM}$-Tris/ $/ \mathrm{HCl}, \mathrm{pH} 8.0 ; 1 \mathrm{mM}$-EDTA $)$, and stored at $4{ }^{\circ} \mathrm{C}$.

DNA cloning. Total DNA from $P$. s. tomato strain B88 was partially digested with Sau $3 \mathrm{AI}$ and size-selected on a linear $10-40 \%(\mathrm{w} / \mathrm{v})$ sucrose gradient; fractions containing 20-35 kilobase fragments were identified by agarose gel electrophoresis (Maniatis et al., 1982). The DNA was recovered from these fractions and ligated to pLAFR3 (Staskawicz et al., 1987) DNA that previously had been digested with BamHI and treated with bacterial alkaline phosphatase (Maniatis et al., 1982). Ligation products were packaged in vitro (Silhavy et al., 1984) and used to transfect $E$. coli strain JM107 (Yanisch-Perron et al., 1985). Recombinants were selected on LB agar plates supplemented with $15 \mu \mathrm{g}$ tetracycline $\mathrm{ml}^{-1}, 40 \mu \mathrm{g} \mathrm{X}$-Gal (5-bromo-4-chloro-3-indolyl $\beta$-D-galactoside) $\mathrm{ml}^{-1}$ and $40 \mu \mathrm{M}$-IPTG (isopropyl $\beta$-D-thiogalactopyranoside) and stored in glycerol at $-80^{\circ} \mathrm{C}$ (Silhavy et al., 1984).

$D N A-D N A$ hybridization. In preparation for dot-blot analysis of DNA homology, the DNA in a sample of solution was first sheared by forcing it rapidly through a 25 gauge hypodermic needle five or six times. The sheared DNA was then treated with proteinase $\mathrm{K}\left[0.1 \mathrm{mg}\right.$ enzyme $\mathrm{ml}^{-1} ; 0.5 \% \mathrm{SDS} ; 5.0 \mathrm{mM}$-EDTA (final concentrations); $1 \mathrm{~h}, 37^{\circ} \mathrm{C}$ ], extracted once each with phenol, phenol/chloroform, and chloroform, precipitated with ethanol, and dissolved in $50 \mathrm{~mm}$-sodium phosphate buffer, $\mathrm{pH} 7 \cdot 0$. The DNA concentrations were determined spectrophotometrically (Maniatis et al., 1982), and the solutions were adjusted to contain $20 \mu \mathrm{g} \mathrm{DNA} \mathrm{ml}^{-1}$ and then frozen. Shortly before use, $5 \mu \mathrm{l}$ of each DNA solution was treated with $95 \mu 11 \cdot 5 \mathrm{M}-\mathrm{NaCl}$ plus $0 \cdot 1 \mathrm{M}-\mathrm{NaOH}$ for $20 \mathrm{~min}$ at room temperature and then held on ice. The samples were applied in duplicate to a nitrocellulose membrane in a dot-blot apparatus, and each well was washed with $0.4 \mathrm{ml} 0.5 \mathrm{M}-\mathrm{Tris} / \mathrm{HCl}(\mathrm{pH} 7.5)$ plus $0.5 \mathrm{M}-\mathrm{NaCl}$. The filter was removed from the apparatus, dried, and baked at $80^{\circ} \mathrm{C}$ in a vacuum oven. Total DNA from $P$. s. tomato strain B88 was nick-translated to incorporate [32 P]dATP (Maniatis et al., 1982) and hybridized under stringent conditions (Denny, 1988). After being washed, the membrane was autoradiographed to check for undesired spot spreading, 
and the radioactivity in each spot was quantified by cutting the spot out and counting it in liquid scintillation fluid. Non-specific background was subtracted, and the data were expressed as percentages of the B88 probe hybridizing to itself, which was set at $100 \%$.

$R F L P$ analysis. Total DNA (2-3 $\mu \mathrm{g})$, prepared as described above, was completely digested with either $E c o$ RI or Pst I (4.0 mM-spermidine was included in the reaction mixture to facilitate digestion), electrophoresed on $0.6 \%$ (w/v) agarose gels, and blotted to nitrocellulose membranes (Smith \& Summers, 1980). Selected cosmid clones of $P$. s. tomato DNA were labelled with $\left[{ }^{32} \mathrm{P}\right] \mathrm{dATP}$ and hybridized to membranes. After being washed, the membranes were autoradiographed to visualize the restriction fragments with homology to the cloned $P$. s. tomato DNA probe.

The two sets of autoradiographs from the pathovars were analysed separately. The first step was to assign, in ascending order, a unique number to each band (i.e. a continuous set of numbered fragments was generated from the six different digest/probe combinations in each set of autoradiographs). Each band was considered a separate character, and the fragment profiles were recorded as a string of ones and zeros, indicating, respectively, the presence or absence of a fragment. The proportion of mismatched fragments between pairs of strains $(D)$ was calculated by the equation

$$
D=1-\left[2 n_{x y} /\left(n_{x}+n_{y}\right)\right]
$$

where $n_{x y}$ is the number of fragments shared by the two strains and $n_{x}$ and $n_{y}$ are the numbers of fragments in strain $x$ and strain $y$, respectively. A matrix was constructed with the $D$ values for all pair-wise combinations of strains, and cluster analysis was done by the unweighted pair-group method with averages (UPGMA).

Multilocus enzyme electrophoresis. Techniques for preparing soluble extracts of bacterial enzymes, their electrophoresis on starch gels, and the demonstration of enzyme activity by selective staining are described in detail by Selander et al. (1986). In addition to buffer systems A (Tris/citrate, pH 8.0), C (Poulik, pH 8.7), D (lithium hydroxide, $\mathrm{pH} 8 \cdot 2$ ), E (Tris/malate, $\mathrm{pH} \mathrm{7.4),} \mathrm{G} \mathrm{(phosphate,} \mathrm{pH} 7.0$ ), and I (Tris/EDTA/borate, $\mathrm{pH} 8 \cdot 7$ ), two additional buffer systems were used: $J$, which uses the electrode buffer of $G$ and a $1: 20$ dilution of the electrode buffer for the gel ( $\mathrm{pH} \mathrm{6.7)}$; and $\mathrm{K}$, which is buffer system I modified to contain 2 parts of $\mathrm{G}$ plus 78 parts of $\mathrm{I}$ for the electrode buffer and $0.78 \mathrm{mM}-\mathrm{KH}_{2} \mathrm{PO}_{4}$ and $0.12 \mathrm{~mm}$-citric acid in the system I gel buffer, with the $\mathrm{pH}$ adjusted to $8 \cdot 2$. The buffer systems used for the 26 enzymes assayed were as follows: buffer A, malate dehydrogenase (MDH) and malic enzyme (MAE); C, phenylalanyl leucine peptidase (PE4); D, hexokinase (HEX), phenylalanyl leucine peptidase (PE3) and $\alpha$-naphthyl propionate esterase (ES1); E, phosphoglucose isomerase (PGI), glucose-6-phosphate dehydrogenase (G6P), peroxidase (PER), phosphoglucomutases (PG1 and PG2), leucylalanine peptidase (PE1), phenylalanyl leucine peptidase (PE2) and alkaline phosphatase (ALP); G, NADP-dependent glucose dehydrogenase (GDH), adenylate kinase (ADK), nucleoside phosphorylases (NP1 and NP2) and catalases (CT1 and CT2); I, isocitrate dehydrogenase (IDH), indophenol oxidase (IPO) and $\alpha$-naphthyl acetate esterase (ES2); J, xanthine dehydrogenase (XDH) and NAD-dependent glyceraldehyde phosphate dehydrogenase (GP1); and K, guanine deaminase (GDA). Peptidases were differentiated by mobilities and specificities for four peptidase substrates, but for convenience, three of the peptidases were assayed with phenylalanyl leucine.

Electromorphs of an enzyme were equated with alleles at the corresponding structural gene locus, and electromorph profiles for the set of 26 enzymes assayed were equated with multilocus genotypes. Genetic diversity (h) for a locus was calculated as

$$
h=\left(1-\sum x_{i}^{2}\right) \cdot[n /(n-1)]
$$

where $x_{i}$ is the frequency of the $i$ th allele and $n$ is the number of strains or ETs (Selander et al., 1985, 1986). Genetic distance between pairs of strains was calculated as the proportion of mismatched loci, and cluster analysis was done as indicated above.

\section{RESULTS}

\section{DNA-DNA hybridization}

The $P$. s. tomato strains were from 86 to $131 \%(=100 \%)$ homologous to ${ }^{32} \mathrm{P}$-labelled reference DNA from $P$. $s$. tomato strain B88, whereas the $P$. $s$. syringae strains were from 37 to $47 \%$ homologous to this $P$. s. tomato DNA (Table 1). The occurrence of values much larger than $100 \%$ among the $P$. s. tomato strains indicates that much of the observed variation can be attributed to experimental error. Direct binding assays are inherently variable because of inconsistent binding of DNA to the membrane (Johnson, 1984), and the variation observed among experiments was in line with expectations (see Selander et al., 1985). It is also possible that variation in the quality of the DNA preparations affected the capacity of the bound DNAs to hybridize. 
Table 1. Homology of P. syringae pv. tomato and P. syringae pv. syringae to strain B88 total DNA

Hybridization of the ${ }^{32} \mathrm{P}$-labelled B88 DNA to itself was set at $100 \%$ in each experiment. Hybridization of the other DNAs to this probe are reported as relative percentages \pm SD based on results from 2 to 5 independent experiments (see Methods). As a test of non-specific binding, $E$. coli strain HB101 was $4.9 \pm 1.0 \%$ homologous, and Agrobacterium tumefaciens strain A6 was $1.0 \pm 0.7 \%$ homologous. Abbreviations are: ATCC, American Type Culture Collection, Rockville, Md., USA; CNBP, Collection National de Bactéries Phytopathogènes, Angers, France; NCPPB, National Collection of Plant Pathogenic Bacteria, Harpenden, UK; PDDCC, Plant Diseases Division Culture Collection, Auckland, NZ.

\begin{tabular}{|c|c|c|c|c|c|}
\hline Strain & Percentage homology & Strain & Percentage homology & Strain & Percentage hom \\
\hline P. s. tomato & & P. s. tomato & & P. s. syrin & \\
\hline B88 & $100 \cdot 0$ & JL1053 & $106.8 \pm 9 \cdot 2$ & B48 & $37 \cdot 6 \pm 2 \cdot 2$ \\
\hline B19 & $89.5 \pm 8.3$ & JL1060 & $97.0 \pm 2.47$ & B61 & $42 \cdot 2 \pm 5 \cdot 3$ \\
\hline B117 & $105 \cdot 0 \pm 2 \cdot 6$ & JL1075 & $88.9 \pm 6.3$ & B64 & $37 \cdot 7 \pm 3 \cdot 1$ \\
\hline B118 & $94.9 \pm 4.5$ & JL1105 & $91.2 \pm 8.3$ & B76 & $42 \cdot 3 \pm 2 \cdot 9$ \\
\hline B120 & $86.9 \pm 13.8$ & JL1120 & $97.7 \pm 6.8$ & B78 & $47 \cdot 1 \pm 5 \cdot 4$ \\
\hline B121 & $104 \cdot 6 \pm 8 \cdot 0$ & RG4 & $105 \cdot 0 \pm 2.83$ & B84 & $42 \cdot 8 \pm 4.8$ \\
\hline B122 & $116.5 \pm 4.9$ & NCPPB 2424 & $121.5 \pm 5.0$ & PSC1B & $45 \cdot 5 \pm 2 \cdot 9$ \\
\hline B125 & $124.5 \pm 7.8$ & NCPPB 880 & $92.4 \pm 3.2$ & & \\
\hline B181 & $86.4 \pm 13.6$ & CNBP 1323 & $108 \cdot 0 \pm 9.9$ & & \\
\hline B191 & $92.9 \pm 9.0$ & 10862 & $101 \cdot 2 \pm 11 \cdot 0$ & & \\
\hline T4B1 & $113 \cdot 0 \pm 7 \cdot 1$ & 30555 & $119 \cdot 0 \pm 11 \cdot 3$ & & \\
\hline AV80 & $101 \cdot 2 \pm 11 \cdot 0$ & 31861 & $131 \cdot 5 \pm 9.2$ & & \\
\hline JL1031 & $88.9 \pm 10.6$ & PDDCC 3357 & $96.7 \pm 7 \cdot 5$ & & \\
\hline
\end{tabular}

\section{Multilocus enzyme electrophoresis}

On the basis of results of phenotypic tests (preceding paper: Denny, 1988), a total of 23 strains of $P$. s. tomato and $P$. s. syringae were selected, assigned code numbers, and analysed in a blind experiment. Within this group, 10 electrophoretic types (ETs) were identified by the electromorph profile for 26 polymorphic enzymes (Table 2). The strains could be divided into two groups: group A contained all $17 P$. s. tomato strains in the sample and group B all the $P$. $s$. syringae strains. Most of the $P$. s. tomato strains were identical in multilocus genotype (ET 1), with only four strains representing the other three ETs. In contrast, each $P$. s. syringae strain was distinctive.

Mean genetic diversity $(H)$, which is a measure of the allelic frequency at each locus, was 0.076 for the $P$. s. tomato strains (group A) and 0.479 for the $P$. s. syringae strains (group B) (Table 3 ). When all the strains were combined (group A plus group B), the mean genetic diversity of 0.444 was lower than that of $P$. s. syringae alone because of the large number of less variant $P$.s. tomato strains. When mean genetic diversity was calculated for ETs, the values for $P$. s. tomato and the combined group increased.

Cluster analysis of genetic distances based on enzyme polymorphisms confirmed the separation of the $P$. s. tomato and $P$. s. syringae strains tested (Fig. 1). On average, pairs of isolates of these two pathovars differed at more than $90 \%$ of their loci. All four ETs of $P$. $s$. tomato were closely related, forming a cluster at a genetic distance of about $0 \cdot 23$. The 13 strains in ET 1 were most closely related to the single strain in ET 2, with differences occurring only at the XDH and CT2 loci. The remaining two ETs in group A differed only at the ES1 locus. ET 3 was represented by the second oldest strain (NCPPB 880 from Yugoslavia) and a strain recently isolated in California (JL1053), and ET 4 consisted of the oldest strain in the collection (ATCC 10862).

The depth of genetic divergence among the six ETs of $P$. s. syringae was greater than that of the four ETs of $P$. s. tomato. The most divergent strain, B61 from wheat (ET 10), was separated from the main cluster that contained the remaining five strains in two subclusters. One subcluster had a second wheat strain (B64, ET 5) and a peach strain (B48, ET 6); the other subcluster had a corn strain (PSC1B, ET 7) and two tomato strains (B76, ET 8; B78, ET 9). It is 
$\frac{2}{2}$

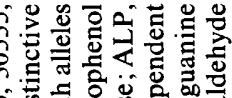

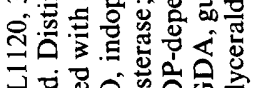

ق

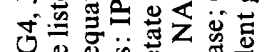

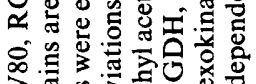

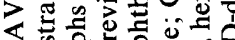

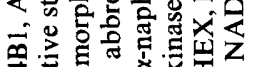

氙

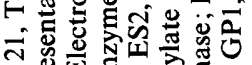

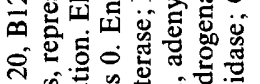

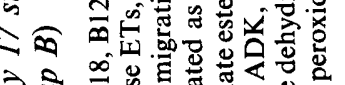

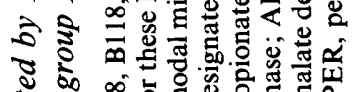

অ

ङ

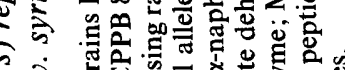

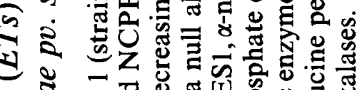

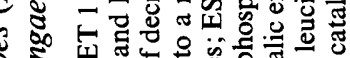

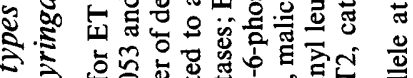

.

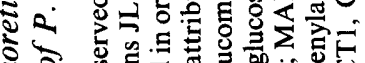

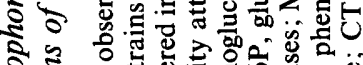

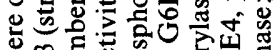

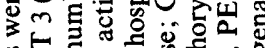

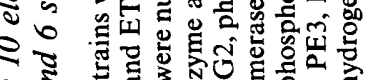

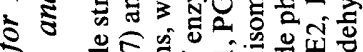

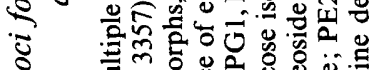

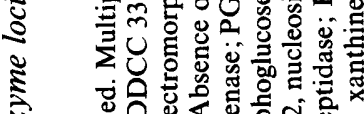

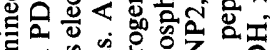

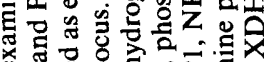

๙

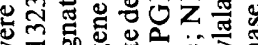

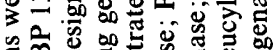

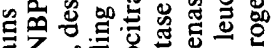

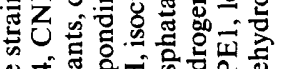

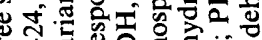

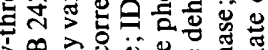

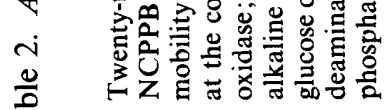

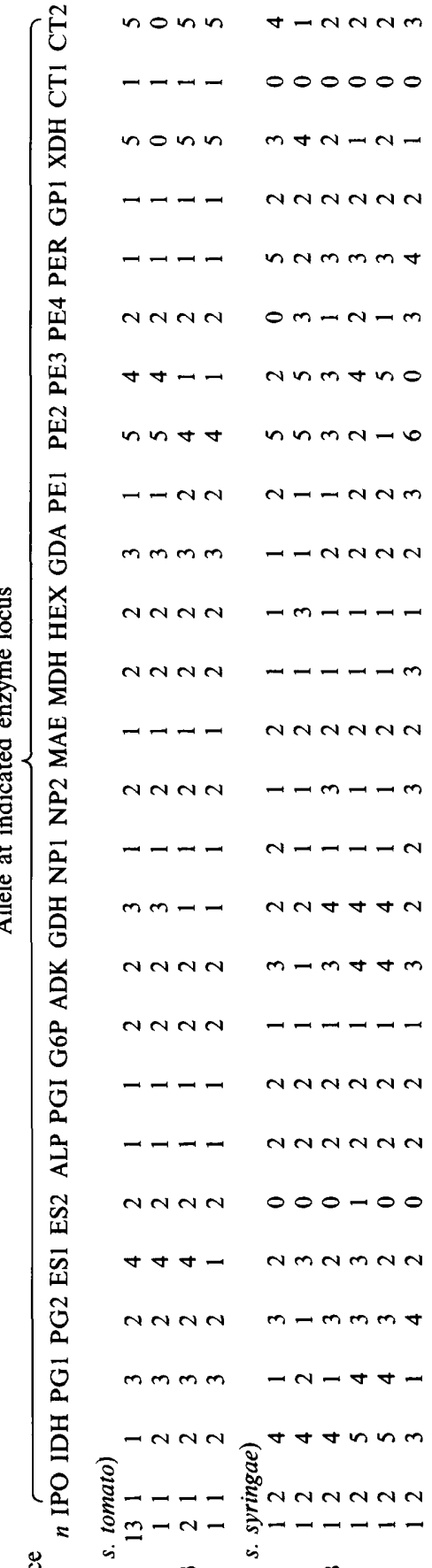

递苟

aं $\tilde{2} \sim \dot{2}$

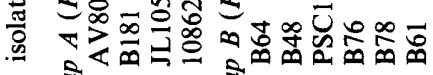

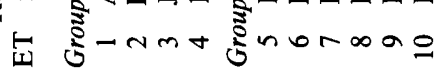




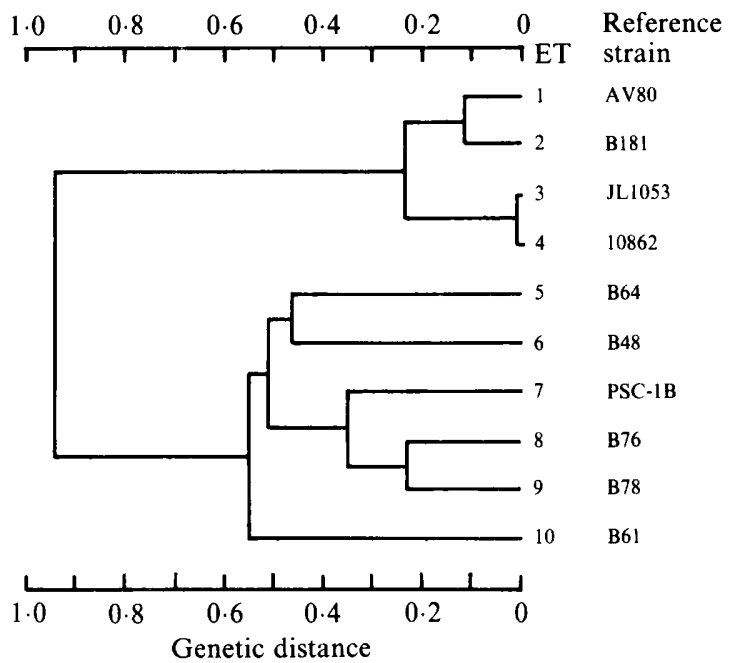

Fig. 1. Genetic relationships among 10 ETs of $P$. s. tomato (ETs 1 to 4 ) and $P$. s. syringae (ETs 5 to 10). The dendrogram was constructed as described in the text based on electromorphs at 26 enzyme loci. See Table 2 for a listing of the strains in each ET.

Table 3. Genetic diversity at 26 enzyme loci among pathovars of $P$. syringae

Mean genetic diversity $(H)$ was calculated by the formula $H=h / n$. The calculations for $P$. s. tomato and $P$. s. syringae used the allele frequencies within each of these two pathovars, whereas the total values were calculated independently from the allele frequencies in the combined sample of strains or ETs.

\begin{tabular}{|c|c|c|c|c|c|c|}
\hline & \multicolumn{2}{|c|}{ No. of: } & \multirow{2}{*}{$\begin{array}{l}\text { Percentage } \\
\text { polymorphic } \\
\text { loci }\end{array}$} & \multirow{2}{*}{$\begin{array}{l}\text { Mean } \\
\text { no. of } \\
\text { alleles }\end{array}$} & \multicolumn{2}{|c|}{$\begin{array}{l}\text { Mean genetic } \\
\text { diversity }\end{array}$} \\
\hline & Isolates & ETs & & & Isolates & ETs \\
\hline $\begin{array}{l}P . s . \text { pv. tomato } \\
P . s . \text { pv. syringae }\end{array}$ & $\begin{array}{r}17 \\
6\end{array}$ & $\begin{array}{l}4 \\
6\end{array}$ & $\begin{array}{l}30 \cdot 8 \\
73 \cdot 1\end{array}$ & $\begin{array}{l}1 \cdot 3 \\
2 \cdot 5\end{array}$ & $\begin{array}{l}0.076 \\
0.479\end{array}$ & $\begin{array}{l}0.179 \\
0 \cdot 479\end{array}$ \\
\hline Total & 23 & 10 & $100 \cdot 0$ & $3 \cdot 5$ & 0.444 & 0.683 \\
\hline
\end{tabular}

interesting to note that the two tomato strains are so different, since both were isolated during the same year in south Georgia.

\section{RFLP analysis}

For this study, three random segments of the genome of $P$. s. tomato strain B88 were cloned in the cosmids pB88-4, pB88-6 and pB88-9; each segment contained approximately 20 kilobases of $P$. s. tomato DNA (about $0.5 \%$ of the total genome). These clones were selected because they had 4-10 evenly distributed $E c o$ RI or $P s t \mathrm{I}$ restriction fragments, the same enzymes used to digest the genomic DNA. There was no cross-hybridization among these three probes (data not shown), an important consideration when the data are to be used in constructing genetic distance dendrograms (Lawson et al., 1986). When used as hybridization probes, these clones detected genomic fragments that ranged in size from approximately 1-20 kilobases. Because the resolution of DNA fragments of this size range on standard agarose gels decreases rapidly with increasing size (Maniatis et al., 1982), only 'major' changes in fragment size were detected in this study. Vector DNA did not hybridize to $P$. s. tomato or $P$. s. syringae DNA under the conditions used.

Selected portions of the autoradiographs of the EcoRI-digested DNAs probed with the three cosmids are shown in Fig. 2. Cosmid pB88-4, which probed the most variable genomic location, 
(a)

$\begin{array}{lllllllll}1 & 2 & 3 & 4 & 5 & 6 & 7 & 8 & 9\end{array}$ (b)

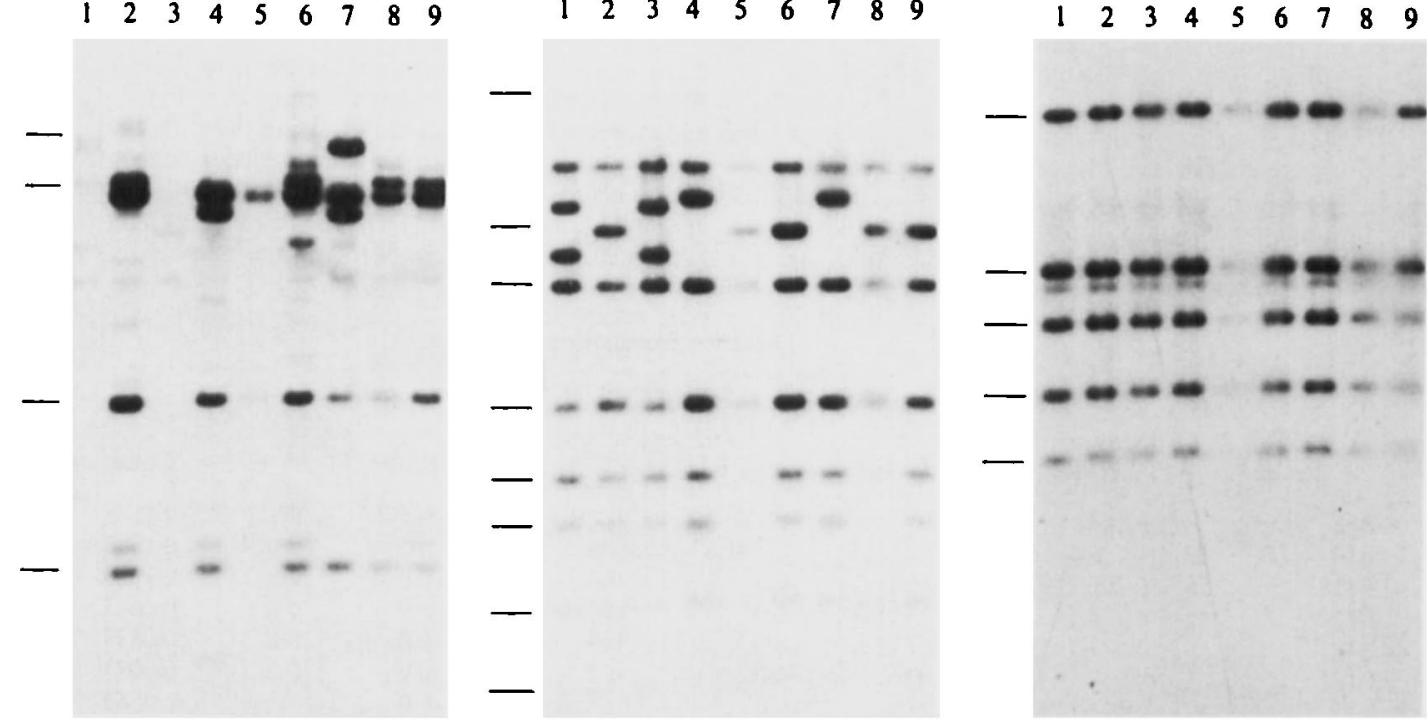

Fig. 2. Selected RFLPs detected by hybridization of ${ }^{32}$ P-labelled cosmids of cloned $P$. s. tomato DNA to $E c o$ RI-digested $P$. s. tomato genomic DNAs bound to a nitrocellulose filter. $(a),(b)$ and $(c)$, cosmids pB88-4, pB88-6 and pB88-9, respectively, used as the hybridization probes. Genomic DNAs: lane 1, 10862; lane 2, CNBP1323; lane 3, NCPPB 880; lane 4, NCPPB 2424; lane 5, PDDCC 3357; lane 6, AV80; lane 7, RG4; lane 8, T4B1; lane 9, B88. Pointers designate the position of EcoRI fragments from the cosmid clones; the largest fragment is the 21.6 kilobase pLAFR3 vector plus the EcoRI-Sau3AI $P$. s. tomato DNA fragment.

hybridized strongly to a few bands and weakly to many bands (more clearly seen in other exposures that are not shown). Most of the strong bands in the genomic lanes were aligned with the restriction fragments generated by digestion of the cloned probes. One band in the genomic digests will never be in alignment, however, since the EcoRI-Sau3AI fragment of $P$. s. tomato DNA that remains attached to the vector will hybridize to a genomic fragment of different size. Weakly hybridizing bands were presumed to represent a sequence in the probe that was partially homologous to sequences repeated elsewhere in the genome. Cosmid pB88-6 detected only one polymorphic fragment with two alternative states. No polymorphisms were detected with cosmid pB88-9, indicating a completely conserved region of the genome. These cosmids hybridized weakly to a number of bands in P. s. syringae genomic DNA (data not shown).

In analysing the data, we assumed that the regions of the genome examined with the hybridization probes are representative of the entire genome. Because the probes were uncharacterized, however, we could not assume the absence of insertion or deletion mutations; consequently, established methods of analysis could not be applied to the data (Whittam et al., 1986; Nei, 1987). Instead, we analysed the data by a method similar to that used for protein polymorphisms. In this case, the presence or absence of each band was recorded for all the strains, and the proportion of mismatched bands $(D)$ calculated as the measure of genetic distance. There were 104 different bands from the $P$. s. tomato strains and 88 different bands from the $P$. s. syringae strains (counting both strongly and weakly hybridizing bands), but no one strain had more than $55 \%$ or $36 \%$ of these bands, respectively.

An example of the distance values for the comparison of strain B88 to all other $P$. s. tomato strains is given in Table 4. For the purpose of this example only, values were calculated for the individual probes and the different digests; it is the combined values in the last column that were normally calculated and used as part of the distance matrix. This analysis confirmed the conclusions based on visual inspection of Fig. 2: cosmid pB88-4 detected the most variation, cosmid pB88-6 detected relatively little variation, and cosmid pB88-9 detected no variation. 
Table 4. Pairwise comparison of the RFLP patterns of strain B88 with those of selected $P$. syringae pv. tomato strains

Each probe (pB88-4, pB88-6 and pB88-9) was hybridized to genomic DNA digested with either EcoRI or Pst I restriction endonucleases. The number of dissimilar restriction fragments in each pairwise combination with strain B88 was determined and distance values were calculated using the formula given in the text. The values in parentheses are the number of restriction fragments that hybridized to a given probe. The number of dissimilar bands in each combination can be calculated by adding the number of bands for strain B88 and the other strain in each pair and multiplying by the distance. When the RFLP pattern of B88 and the paired strain are identical, the distance is zero and the number of fragments was omitted from the Table.

\begin{tabular}{|c|c|c|c|c|c|c|c|}
\hline \multirow[b]{3}{*}{ Strain } & \multicolumn{7}{|c|}{ Distance from strain B88 using: } \\
\hline & \multicolumn{2}{|c|}{ Probe 4} & \multicolumn{2}{|c|}{ Probe 6} & \multicolumn{2}{|c|}{ Probe 9} & \multirow[b]{2}{*}{ Combined } \\
\hline & EcoRI & Pst I & Eco RI & Pst I & EcoRI & Pst I & \\
\hline B88 & $0(13)$ & $0(16)$ & $0(7)$ & $0(10)$ & $0(6)$ & $0(5)$ & $0(57)$ \\
\hline B19 & ND & $0.385(10)$ & ND & 0.0 & ND & 0.0 & $0 \cdot 1786$ \\
\hline B118 & $0 \cdot 200(12)$ & $0.214(12)$ & $0 \cdot 0$ & $0 \cdot 0$ & $0 \cdot 0$ & $0 \cdot 0$ & $0 \cdot 1009$ \\
\hline B120 & $0 \cdot 120(12)$ & $0 \cdot 133(14)$ & $0 \cdot 0$ & $0 \cdot 0$ & $0 \cdot 0$ & $0 \cdot 0$ & 0.0631 \\
\hline B121 & $0.071(15)$ & $0.267(14)$ & $0 \cdot 0$ & $0 \cdot 0$ & $0 \cdot 0$ & $0 \cdot 0$ & 0.0877 \\
\hline B181 & $0.037(14)$ & $0.0(16)$ & $0 \cdot 0$ & 0.0 & 0.0 & $0 \cdot 0$ & 0.0087 \\
\hline T4B 1 & $0.111(14)$ & ND & 0.0 & ND & 0.0 & ND & 0.0566 \\
\hline AV80 & $0.071(15)$ & $0.267(14)$ & $0 \cdot 0$ & 0.0 & $0 \cdot 0$ & $0 \cdot 0$ & 0.0877 \\
\hline JL1053 & $0.500(7)$ & 0.259 (11) & $0.333(8)$ & $0 \cdot 100(10)$ & 0.0 & $0 \cdot 0$ & 0.2115 \\
\hline JL1120 & $0 \cdot 154$ (13) & 0.200 (14) & 0.0 & 0.0 & 0.0 & 0.0 & 0.0893 \\
\hline RG4 & $0.524(8)$ & $0.520(9)$ & $0 \cdot 143(7)$ & $0 \cdot 100(10)$ & 0.0 & 0.0 & $0 \cdot 2745$ \\
\hline NCPPB 2424 & $0 \cdot 304(10)$ & $0.448(13)$ & $0 \cdot 143(7)$ & $0 \cdot 100(10)$ & 0.0 & $0 \cdot 0$ & 0.2222 \\
\hline NCPPB 880 & $0.875(3)$ & $0.790(3)$ & $0 \cdot 200(8)$ & $0 \cdot 182(12)$ & $0 \cdot 0$ & 0.0 & 0.3830 \\
\hline CNBP 1323 & 0.259 (14) & 0.200 (14) & 0.0 & 0.0 & 0.0 & $0 \cdot 0$ & $0 \cdot 1150$ \\
\hline 10862 & $0.900(7)$ & $0.826(7)$ & $0 \cdot 200(8)$ & $0.182(12)$ & 0.0 & 0.0 & 0.4314 \\
\hline 30555 & $0.072(15)$ & $0.226(15)$ & 0.0 & 0.0 & $0 \cdot 0$ & 0.0 & 0.0783 \\
\hline PDDCC 3357 & $0.333(8)$ & $0.600(9)$ & 0.0 & $0 \cdot 0$ & $0 \cdot 0$ & $0 \cdot 0$ & $0 \cdot 2157$ \\
\hline
\end{tabular}

ND, No data due to poor digestion of the genomic DNA.

This analysis showed that NCPPB 880 and ATCC 10862 were the most atypical strains. The results from the EcoRI-digested DNAs were very similar to those from the PstI-digested DNAs, which suggests that increasing the number of probes to examine a larger percentage of the genome should give more useful information than examining one region of genomic DNA digested with many different restriction enzyes.

The RFLP distance matrices were analysed to produce the dendrograms in Fig. 3. Within the $P$. s. tomato group (Fig. $3 a$ ), strains NCPPB 880 and ATCC 10862 fell in a separate cluster and were clearly different from the other strains. In the other cluster, all the other $P$. s. tomato strains were slightly different, but strain JL1053 was the most unusual. The dendrogram for the $P$. $s$. syringae group (Fig. $3 b$ ) is presented separately since there were no shared hybridization bands that could be used to determine the relationship between the $P$. s. syringae and $P$. s. tomato strains. This limitation of RFLP analysis is the trade-off that must be accepted for the method's enhanced sensitivity to small differences.

There were two major clusters of $P$. s. syringae strains. One cluster contained the corn and the two wheat strains (PSC1B, B64 and B61), and the second cluster consisted of the peach strain and the two tomato strains (B48, B76 and B78). This analysis separated the strains that are pathogenic on monocots from those that are pathogenic on dicots. Except for the clustering of the two tomato strains, the relationships among the $P$. s. syringae strains from the RFLP analysis were different from those based on enzyme polymorphisms. However, the results based on RFLPs should be considered preliminary, because the low homology between the $P$. s. tomato probes and $P$. s. syringae genomic DNAs resulted in a number of weakly hybridizing bands being used in the analysis. 

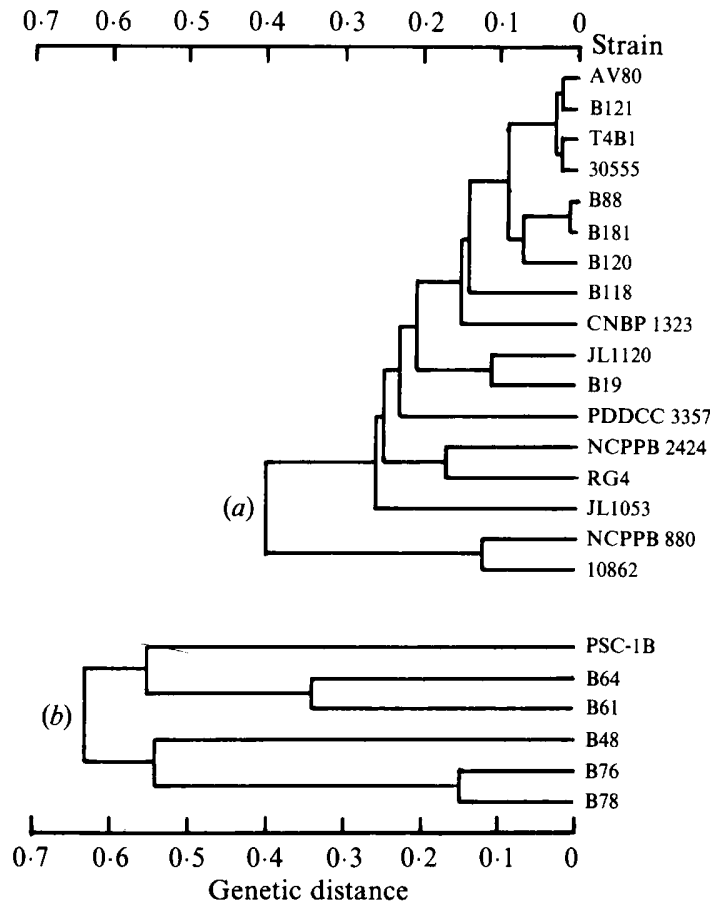

Fig. 3. Genetic relationships within the two $P$. syringae pathovars. The dendrograms were constructed based on RFLP analysis as described in the text for: (a) 17 strains of $P$. s. tomato; (b) 6 strains of $P$. s. syringae.

\section{DISCUSSION}

Our ability to measure genetic diversity with the DNA-DNA hybridization assay was limited by the variability inherent in the procedure. Little could be concluded regarding the extent of diversity within the two pathovars, but the low degree of homology between the $P$. s. syringae DNAs and the $P$. s. tomato reference DNA clearly distinguished between the two pathovars. Our $42 \%$ average homology between pathovars is less than the 58 to $66 \%$ homology values reported by Palleroni et al. (1972) and Pecknold \& Grogan (1973), presumably because we used more stringent hybridization conditions $\left(T_{\mathrm{m}}-20^{\circ} \mathrm{C}\right)$ and a different washing procedure $\left(T_{\mathrm{m}}-15^{\circ} \mathrm{C}\right)$. Recent interpretations of DNA hybridization data have suggested that bacteria should be considered separate species if they are less than 60 to $70 \%$ homologous under optimal conditions (Schleifer \& Stackebrandt, 1983; Brenner, 1981; Johnson, 1984). If this criterion is applied to $P$. syringae pathovars, then $P$. s. tomato should be considered specifically distinct from $P$. s. syringae.

Multilocus enzyme electrophoresis strongly supported the conclusion that $P$. s. tomato and $P$. s. syringae are distinct species. The genetic distance between the pathovars $(D>90 \%)$ was unusually high for strains of a single species (Selander, 1985). Furthermore, although the sample size is too small to warrant firm conclusions, the rather large mean genetic diversity among strains of $P$. s. syringae $(H=0.479)$ suggested that further study will lead to the taxonomic subdivision of this pathovar. The level of genetic diversity in $P$. s. syringae appeared to support the hypothesis that variation was higher among strains from diverse habitats (e.g. wide host range $P$. s. syringae) than among those from a uniform habitat (e.g. P. s. tomato from tomato) (Hildebrand et al., 1982).

For $P$. s. tomato, the genetic relationships detected by RFLP analysis were similar to those obtained by multilocus enzyme electrophoresis, except that RFLPs discriminated among all the $P$. s. tomato strains. The greater sensitivity of the RFLP analysis is illustrated by the relationship 
between strains B 88 and B181, for which a mismatch in one of 58 bands resulted in a distance of $1 \%$. It is possible, however, that the RFLP analysis detected an uncharacteristic amount of variation among the $P$. s. tomato strains because of the apparent repeated sequence on the cloned DNA in cosmid pB88-4. If such a repeated sequence is part of a mobile genetic element, then this cosmid probe might have examined unusually variable, non-representative regions of the genome. Seven of the $P$. s. tomato strains are identical when only the bands that hybridize strongly to cosmid pB88-4 are used in the RFLP analysis, which is more like the results from the enzyme analysis. Examining more of the genome with additional cloned probes would resolve this uncertainty.

An alternative method for using RFLPs to study variation in bacteria is to examine the electrophoretic profiles of DNA digests immediately after staining agarose gels with ethidium bromide (Glynn et al., 1985; Hartung \& Civerolo, 1987). These DNA 'fingerprints' offer the advantages of simplicity and speed, but several disadvantages of this method should be considered. First, the large number of DNA bands on the gel means that only marked differences will be observable, whereas differences between closely related strains such as those detected with cosmid pB88-6 will likely go unnoticed. Second, without hybridization probes to detect homology, the relationships between strains with different fingerprints must be established by other means. For example, the fact that differences between the DNA fingerprints of $P$. s. tomato strains ATCC 10862 and B88 (unpublished data from DNA gels used to produce the Southern blots for this research) were almost as large as those observed when a $P$. s. syringae strain was compared to B88 might lead to the erroneous conclusion that the two $P$. $s$. tomato strains were not related if only the DNA fingerprints were considered. The combination of these factors would make it impossible to quantify relationships, as was done in this study.

In work similar to ours, Lazo et al. (1987) recently reported using RFLP analysis to distinguish pathovars of Xanthomonas campestris. They found some probes that would differentiate all 26 pathovars, but in contrast to our results with $P$. s. tomato and $P$. s. syringae, some regions of the $X$. campestris genome were highly conserved among all the pathovars examined (e.g. at the species level). Lawson et al. (1986) used RFLP analysis in a preliminary study to demonstrate genotypic diversity among some $P$. syringae pathovars and rhizosphere-associated fluorescent pseudomonads. They also used a method of data analysis similar to ours, but did not combine data from multiple probes to produce a functional dendrogram. Even more sophisticated use of RFLPs than what we describe is possible with probes that have been restriction mapped. With well-characterized probes, it would be possible to calculate the proportion of base pair substitution between pairs of strains (Nei, 1987).

There are many ways that enzyme electrophoresis and RFLP analyses may aid in the identification of bacteria. These methods could be used to characterize strains of bacteria found in agro-ecosystems (Lawson et al., 1986). Besides providing information on the genetic structures of natural populations, the ability to identify clonally related individuals would be especially useful in epidemiological research. It is also likely that specific hybridizaton probes could be developed to rapidly differentiate related strains of bacteria. The poor hybridization of $P$. s. tomato clones to $P$. s. syringae DNA is a good indication of the feasibility of this approach, and a probe to identify $X$. campestris pv. phaseolicola has been reported (Roth \& Johnson, 1985). These procedures might also be developed to the point where they could confirm the identity of non-pathogenic variants and simplify the identification of pathogens isolated from unusual environments (e.g. non-host or non-plant associations), which at the present time can be quite difficult (Schroth et al., 1981; Palleroni, 1984).

The recovery of closely related strains of $P$. $s$. tomato from around the world suggests that this bacterium was recently disseminated. The most likely mechanism of dissemination is by contaminated seed (McCarter et al., 1983) and infected plants (Bonn et al., 1985). The requirements of exploiting a narrow ecological niche (the tomato plant), coupled with the purging of variation through stochastic extinction and periodic selection of clonal cell lines, could explain the low genetic diversity observed within P. s. tomato (Hildebrand et al., 1982; Selander, 1985). The relatively high genetic diversity within $P$. s. syringae may reflect one of several situations. If some strains of $P$. s. syringae have strong host preferences, the same 
processes that affect $P$. s. tomato, operating in conjunction with multiple hosts, could result in genetically diverse clusters. A generally low degree of host specificity, however, would also result in a high degree of diversity, but clusters would not correlate with the hosts from which the strains were isolated. The results from the enzyme polymorphism analysis suggest that this latter possibility is more likely, but many more strains must be examined before reaching a firm conclusion.

We thank C. P. Benner for technical assistance, W. W. Anderson for use of University of Georgia Genetic Department computing facility, and R. M. Ball for writing the computer program to analyse RFLPs. T. S. Whittam provided helpful discussions. This work was supported in part by a Faculty Research Grant from the University of Georgia Research Foundation (T.P.D.) and by NIH grant AI 22144 (R.K.S.).

\section{REFERENCES}

BonN, W. G., Gitaitis, R. D. \& MacNeill, B. H. (1985). Epiphytic survival of Pseudomonas syringae pv. tomato on tomato transplants shipped from Georgia. Plant Disease 69, 58-60.

BRENNER, D. J. (1981). Introduction to the family Enterobacteriaceae. In The Prokaryotes, vol. II, pp. 1105-1127. Edited by M. P. Starr, H. Stolp, H. G. Truper, A. Balows \& H. G. Schlegel. Berlin: Springer-Verlag.

DenNy, T. P. (1988). Phenotypic diversity in Pseudomonas syringae pv. tomato. Journal of General Microbiology 134, 1939-1948.

GlynN, P., Higgins, P., Squartini, A. \& O'Gara, F. (1985). Strain differentiation in Rhizobium trifolii using DNA restriction analysis, plasmid DNA profiles and intrinsic antibiotic resistances. FEMS Microbiology Letters 30, 177-182.

Hartung, J. S. \& Civerolo, E. L. (1987). Genomic fingerprints of Xanthomonas campestris pv. citri strains from Asia, South America and Florida. Phytopathology 77, 282-285.

Hildebrand, D. C., Schroth, M. N. \& Huisman, O. C. (1982). The DNA homology matrix and nonrandom variation concepts as the basis for the taxonomic treatment of plant pathogenic and other bacteria. Annual Review of Phytopathology 20, 235256.

Johnson, J. L. (1984). Nucleic acids in bacterial classification. In Bergey's Manual of Systematic Bacteriology, vol. 1, pp. 8-11. Edited by N. R. Krieg. Baltimore: Williams \& Wilkins.

Lawson, E. C., Jonsson, C. B. \& Hemming, B. C. (1986). Genotypic diversity of fluorescent pseudomonads as revealed by southern hybridization analysis with siderophore-related gene probes. In Iron, Siderophores, and Plant Diseases, pp. 315-329. Edited by T. R. Swinburne. New York: Plenum Press.

Lazo, G. R., Roffey, R. \& Gabriel, D. W. (1987). Pathovars of Xanthomonas campestris are distinguishable by restriction fragment-length polymorphism. International Journal of Systematic Bacteriology 37, 214-221.

Maniatis, T., Fritsch, E. F. \& Sambrook, J. (1982). Molecular Cloning: a Laboratory Manual. Cold Spring Harbor, NY: Cold Spring Harbor Laboratory.

McCarter, S. M., Jones, J. B., Gitaitis, R. D. \& SMItLEY, D. R. (1983). Survival of Pseudomonas syringae pv. tomato in association with tomato seed, soil, host tissue, and epiphytic weed hosts in Georgia. Phytopathology 73, 1393-1398.

NEI, M. (1987). Molecular Evolutionary Biology. New York: Columbia University Press.

NeI, M. \& LI, W.-H. (1979). Mathematical model for studying genetic variation in terms of restriction endonucleases. Proceedings of the National Academy of Sciences of the United States of America 76, 52695273.

Palleroni, N. J. (1984). Family I. Pseudomonadaceae. In Bergey's Manual of Systematic Bacteriology, vol. 1, pp. 141-219. Edited by N. R. Krieg. Baltimore: Williams \& Wilkins.

Palleroni, N. J., Ballard, R. W., Ralston, E. \& DoudorofF, M. (1972). Deoxyribonucleic acid homologies among some Pseudomonas species. Journal of Bacteriology 110, 1-11.

Pecknold, P. C. \& Grogan, R. G. (1973). Deoxyribonucleic acid homology groups among phytopathogenic Pseudomonas species. International Journal of Systematic Bacteriology 23, 111-121.

RoTH, D. A. \& Johnson, J. (1985). Cloned DNA fragments as hybridization probes to identify Xanthomonas campestris pv. phaseoli. Phytopathology 75, 1321.

Schleifer, K. H. \& Stackebrandt, E. (1983). Molecular systematics of prokaryotes. Annual Review of Microbiology 37, 143-187.

SCHROTH, M. N., Hildebrand, D. C. \& StaRR, M. P. (1981). Phytopathogenic members of the genus Pseudomonas. In The Prokaryotes, pp. 701-718. Edited by M. P. Starr, H. Stolp, H. G. Truper, A. Balows \& H. G. Schlegel. Berlin: Springer-Verlag.

SElander, R. K. (1985). Protein polymorphism and the genetic structure of natural populations of bacteria. In Population Genetics and Molecular Evolution, pp. 85-106. Edited by T. Ohta \& K. Aoki. Berlin: Springer-Verlag.

Selander, R. K., MCKINNEy, R. M., WhitTaM, T. S., Bibb, W. F., BrenNer, D. J., Nolte, F. S. \& PatTison, P. E. (1985). Genetic structure of populations of Legionella pneumophila. Journal of Bacteriology 163, 1021-1037.

Selander, R. K., Caugant, D. A., Ochman, H., Musser, J. M., Gilmour, M. N. \& WhitTam, T. S. (1986). Methods of multilocus enzyme electrophoresis for bacterial population genetics and systematics. Applied Environmental Microbiology 51, 873-884. 
Silhavy, T. J., Berman, M. L. \& ENQUist, L. W. (1984). Experiments with Gene Fusions. Cold Spring Harbor, NY: Cold Spring Harbor Laboratory.

Smith, G. E. \& Summers, M. D. (1980). The bidirectional transfer of DNA and RNA to nitrocellulose or diazobenzyloxymethyl-paper. Analytical Biochemistry 109, 123-129.

Staskawicz, B., Dahlbeck, D., KeEN, N. \& NaPoli, C. (1987). Molecular characterization of cloned avirulence genes from race 0 and race 1 of Pseudomonas syringae pv. glycinea. Journal of Bacteriology 169, 5789-5794.

Whittam, T. S., Clarke, A. G., Stoneking, M. CANN, R. L. \& Wilson, A. C. (1986). Allelic variation in human mitochondrial genes based on patterns of restriction site polymorphism. Proceedings of the National Academy of Sciences of the United States of America 83, 9611-9615.

Yanisch-Perron, C., Vieira, J. \& Messing, J. (1985). Improved M13 phage cloning vectors and host strains: nucleotide sequences of the $\mathrm{M} 13 \mathrm{mp} 18$ and pUC19 vectors. Gene 33, 103-119.

YounG, J. M., DYe, D. W., BRadbURY, J. F., Panagopoulos, C. G. \& RobBs, C. F. (1978). A proposed nomenclature and classification for plant pathogenic bacteria. New Zealand Journal of Agricultural Research 21, 153-177. 